\title{
Prediksi Hambatan Kapal dengan Menggunakan Metode Overset Mesh pada Kapal Planing Hull
}

\author{
Abubakar Fathuddiin ${ }^{1}$, Samuel ${ }^{1}$, Kiryanto ${ }^{1}$, Aulia Widyandari ${ }^{2}$ \\ ${ }^{1}$ Departemen Teknik Perkapalan, Fakultas Teknik, Universitas Diponegoro, Semarang, \\ Indonesia \\ ${ }^{2}$ Departemen Teknik Perkapalan, Sekolah Vokasi, Universitas Diponegoro, Semarang, \\ Indonesia \\ Email: abubakar.fathuddiin@gmail.com
}

Received 20 April 2020 | Revised 27 Mei 2020 | Accepted 29 Mei 2020

\begin{abstract}
ABSTRAK
Prediksi hambatan kapal tipe planing lebih rumit dibanding dengan tipe displacement, hal ini disebabkan oleh gaya hidrodinamis yang lebih dominan pada bagian bawah kapal. Karakteristik hambatan kapal tipe planing sangat dipengaruhi oleh gerakan trim dan heave. Selain itu, bentuk hullform juga mempengaruhi hambatan kapal; seperti sudut dead-rise, chine, strip, stephull, dan lain-lain. Solusi untuk memprediksi hambatan kapal dengan menggunakan Finite Volume Method (FVM). Persamaan RANS (ReynoldsAveraged Navier-Stokes) dengan model turbulensi k-E untuk memprediksi aliran turbulen dan Volume of Fluid (VOF) untuk mempresentasikan aliran 2 fasa. Pada penelitian ini digunakan metode overset mesh untuk memprediksi hambatan kapal agar mendapatkan akurasi yang baik. Hasil simulasi hambatan menunjukkan trend yang baik. Pada kecepatan tinggi, prediksi hambatan tidak memiliki hasil yang baik. Solusi yang ditawarkan pada Numerical ventilation problem (NVP) adalah dengan menggunakan metode phase replacement.
\end{abstract}

Kata kunci: CFD, planing hull, RANS, overset mesh, NVP

\begin{abstract}
The prediction of planing hull resistance is more complicated than the displacement hull. It is caused by the more dominant hydrodynamic force at the bottom of the ship. The planing hull resistance characteristics are strongly influenced by trim and heave movements. In addition, the shape of the hullform also affects the ship's resistance, such as dead-rise angle, chine, strip, stephull, and others. The solution to predict ship resistance is by using the Finite Volume Method (FVM). RANS (Reynolds-Averaged Navier-Stokes) equation $k$ - $\varepsilon$ turbulence model was used to predict turbulent flow and Volume of Fluid (VOF) to present 2 phase flow. In this study, the overset mesh method was used to predict ship resistance in order to get good accuracy. Resistance simulation results showed a good trend. At high speeds, the prediction of resistance did not have good results. The solution offered in the Numerical ventilation problem (NVP) was to use the phase replacement method.
\end{abstract}

Keywords: CFD, planing hull, RANS, overset mesh, NVP 


\section{PENDAHULUAN}

Perkembangan teknologi komputasi memudahkan proses analisa suatu objek. Pada simulasi eksperimen akan membutuhkan banyak model untuk mendapatkan hasil yang diinginkan, sehingga menghabiskan waktu dan biaya dalam setiap pemodelan. Namun sekarang dipermudah dengan dengan adanya software yang dapat menghemat waktu dan biaya. Selain itu dapat menganalisa bentuk yang lebih rumit yang tidak dapat diselesaikan dengan rumus pendekatan.

Gerald Fridsma pada tahun 1969 melakukan eksperimen mengenai kapal cepat atau kapal tipe planing hull. Pada penelitian yang dilakukannya, beberapa variabel panjang hull (lambung), displacement, LCG (Longitudinal Center of Gravity), sudut dead-rise, dan kecepatan pada dua kondisi, kondisi tenang (smooth-water) dan kondisi dengan gelombang (rough-water). Hasil yang didapat berupa hambatan, trim (rotasi terhadap sumbu y), heave (kenaikan terhadap sumbu z) hingga respon terhadap gelombang [1]. Sehingga hasil eksperimen beliau banyak digunakan oleh peneliti sebagai objek validasi dalam penelitian dengan berbagai metode yang digunakan. Mulai dengan metode pendekatan empiris hingga komputasi numerik.

Kapal dikatakan planing hull apabila tekanan hidrostatik lebih kecil dibanding tekanan hidrodinamik [2] atau berada pada Froude Number (Fr) $\geq 1-1.2$ [3]. Sehingga kapal tipe planning hull lebih rumit dibandingkan dengan displacement hull, karena membutuhkan interaksi antara air dan udara (komputasi multifasa). Karakteristik planing hull memiliki trim dan heave yang akan terintegrasi bentuk hull, chine, strakes, dead-rise angle dan Fr tinggi. Beberapa penelitian sebelumnya mengenai komputasi numerik kapal tipe planing dengan Computational Fluid Dynamics (CFD) [2, 4, 5, 6], komputasi numerik Fridsma hullform dengan menggunakan metode moving grid $[7,8]$ dan komputasi numerik dengan metode overset mesh [9, 10]. Pada penelitian tersebut menggunakan Finite Volume Method (FVM), Reynolds-Averaged Navier-Stokes (RANS), dan Volume of Fluid (VOF) dalam memprediksi karakteristik kapal dengan tipe planing. Metode FVM dapat memprediksi hambatan, trim dan heave secara akurat.

Overset mesh merupakan metode mesh yang sering digunakan untuk simulasi benda-benda yang dapat bergerak bebas pada suatu fluida. Contohnya seperti benda jatuh, propeller dan lain sebagainya. Sehingga baik digunakan dalam memprediksi karakteristik kapal bertipe planing. Beberapa contoh peneliti sebelumnya yang menerapkan metode overset mesh yaitu Wheeler dan Sukas $[9,10]$.

Software CFD masih memiliki kekurangan, yaitu keetidakmampuan memprediksi hambatan pada Fr tinggi. Sering terjadi ventilasi atau tercampurnya fasa air dan udara, sehingga mengakibatkan kecilnya nilai hambatan. Masalah ini sering dikenal dengan Numerical Ventilatian Problem (NVP). Pada penelitian Ahmet Gultekin Avci dan Baris Barlas menyimpulkan metode untuk mengatasi Numerical Ventilatian Problem (NVP) dengan mengalikan hasil dengan 1.15 dan dengan mengganti fasa (phase replacement) [4].

Manfaat dari penelitian ini yaitu memberikan informasi mengenai metode overset mesh dan metode phase replacement untuk mendapatkan prediksi yang akurat dalam simulasi kapal bertipe planing hull.

\section{METODOLOGI}

\subsection{Objek Penelitian}

Pada penelitian ini akan dipakai data dari Fridsma hullform dalam ekperimennya pada tahun 1969. Khususnya hasil dari pengujian pada kondisi air tenang (calm water). Dan konfigurasi yang akan divalidasi yaitu model F dan G. Data eksperimen untuk model F dan G pada Tabel 1. 
Tabel 1. Data fridsma F dan G [1]

\begin{tabular}{ccc}
\hline Parameter & Fridsma $-\mathrm{F}$ & Fridsma $-\mathrm{G}$ \\
\hline $\mathrm{L}(\mathrm{m})$ & 1.143 & 1.143 \\
$\mathrm{~B}(\mathrm{~m})$ & 0.229 & 0.229 \\
$\mathrm{~L} / \mathrm{B}$ & 5 & 5 \\
$\mathrm{~T}_{\mathrm{AP}}(\mathrm{m})$ & 0.075 & 0.075 \\
$\beta(\mathrm{deg})$ & 20 & 20 \\
LCG dari AP $(\mathrm{m})$ & 0.480 & 0.480 \\
VCG dari lunas $(\mathrm{m})$ & 0.067 & 0.067 \\
$\Delta(\mathrm{Kg})$ & 10.890 & 10.890 \\
$\mathrm{I}_{\mathrm{yy}}=\mathrm{I}_{\mathrm{zz}}\left(\mathrm{Kg} \cdot \mathrm{m}^{2}\right)$ & 0.233 & 0.233 \\
$\tau_{\mathrm{o}}(\mathrm{deg})$ & 1 & 1 \\
$\mathrm{Fr}$ & 1.2 & 1.8 \\
Kecepatan $(\mathrm{m} / \mathrm{s})$ & 3.985 & 5.977 \\
\hline
\end{tabular}

Data yang diberikan Gerald Fridsma berupa hullform dengan persamaan matematika berupa elips untuk bentuk haluannya seperti pada Gambar 1.

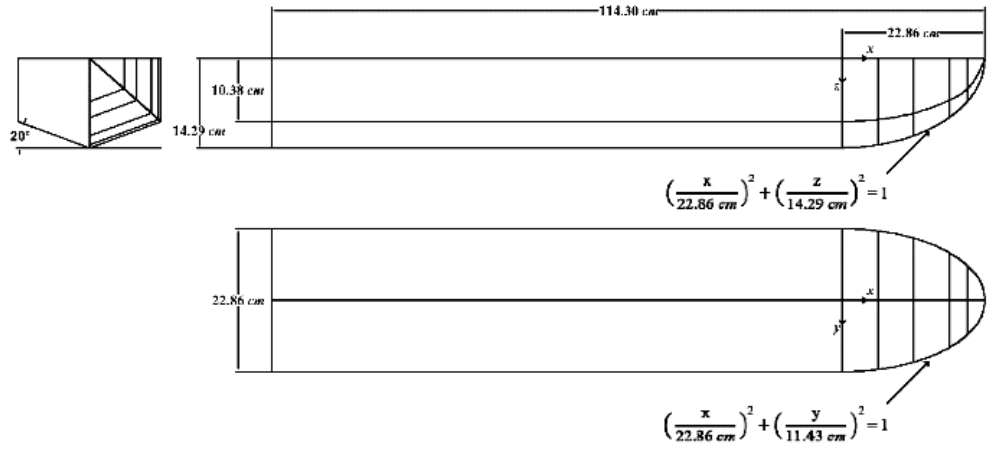

Gambar 1. Fridsma hullform [1]

Fridsma hullform dimodelkan dengan metode NURBS (Non-Uniform, Rational B-spline Surface). Yaitu permodelan $3 D$ surface dengan metode komputasi untuk mempresentasikan garis dan surface yang sebelumnya dalam bentuk persamaan matematika. Pemodelan Fridsma hullform menggunakan surface tertutup (solid) seperti Gambar 2, agar tidak terjadi error pembacaan dalam software simulasi.
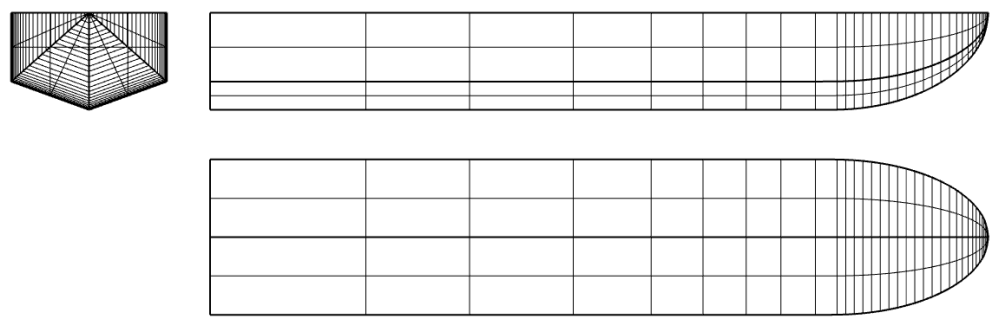

\subsection{Tinjauan Teoritis}

Gambar 2. Pemodelan 3D fridsma hullform

Tujuan penting dari setiap program CFD adalah untuk menyelesaikan persamaan dengan menggunakan pendekatan boundary dan initial conditions. Persamaan Reynolds - averaged Navier - Stokes (RANS) mempresentasikan hukum konservasi massa dan momentum. Setiap cell diasumsikan sebagai volum fraksi yang memiliki nilai 1 dan 0 . Fungsi fluida air dan udara tergantung dari properti volume fraksi. Permukaan air laut diasumsikan F, sebagai hukum konservasi: 


$$
\frac{\delta F}{\delta t}+\frac{\delta u F}{\delta x}+\frac{\delta v F}{\delta y}+\frac{\delta w F}{\beta z}=0
$$

Persamaan RANS dikembangkan berdasarkan konsep bahwa kecepatan dan panjang kapal cukup untuk menggambarkan efek turbulensi di sekitar lambung. Dalam perhitungan, model turbulensi $k-\varepsilon$ yang berfungsi sebagai dinding yang digunakan untuk menggambarkan efek turbulensi pada aliran [11].

Wall function $(y+)$ yaitu dinding pemisah antara dinding (wall) dengan aliran fluida. Berfungsi untuk menangkap boundary layer yang berperan penting dalam perhitungan hambatan (drag). Nilai $y+$ berperan penting untuk mengurangi ketidakuratan perhitungan. Ahmet Gultekin pada penelitiannya menggunakan nilai $y+$ antara $45-60$ untuk mendapatkan hasil yang akurat [4]. Perhitungan nilai $y+$ menurut ITTC [12], yaitu:

$$
\frac{y}{L}=\frac{y^{+}}{R_{e} \sqrt{\frac{C_{f}}{2}}}
$$

Dimana y adalah tebal layer pertama, $\mathrm{L}$ adalah panjang objek, $\mathrm{R}_{\mathrm{e}}$ adalah reynold number dan $\mathrm{C}_{\mathrm{f}}$ adalah estimasi dari koefisien gesek permukaan objek.

Overset mesh merupakan metode mesh dengan cara donor - acceptor cells. Sehingga ada lebih dari satu geometri, background sebagai pendonor, dan overset sebagai penerima donor. Sel aktif terdapat disetiap ujung geometri overset yang berperan sebagai perantara donor - acceptor cells. Sedangkan sel pasif terdapat pada background yang digantikan oleh sel-sel overset [13].



Gambar 3. Transfer data antara overset mesh (merah) dengan background mesh (biru), dimana acceptor cell (jingga) menerima data dari donor cell (hijau) [13]

Time-step digunakan dalam perhitungan aliran unsteady. Time step merupakan interval periode untuk setiap perhitungan iterasi. Semakin kesil nilai membuat hasil semakin akurat, dan sebaliknya. Untuk menentukan time-step pada perhitungan CFD tergantung pada kecepatan kapal. Semakin cepat kapal maka semakin kecil time-step yang digunakan. Berdasarkan perhitungan yang direkomendasikan oleh ITTC [12] pada Persamaan 3. Dengan L sebagai panjang kapal dan U sebagai kecepatan kapal.

$$
\Delta t \text { ITTC }=0.005 \sim 0.01 \frac{L}{U}
$$

\subsection{Metode Penelitian}

Berdasarkan metode overset mesh, pembuatan virtual towing tank dibagi menjadi dua geometri yaitu background sebagai donor dan overset sebagai acceptor. Dimensi yang digunakan dalam penelitian ini seperti tertera pada Tabel 2 dan Gambar 4 sebagai visualisasinya. Dengan L adalah panjang kapal, H adalah tinggi kapal, dan B adalah lebar kapal. 
Tabel 2. Dimensi virtual towing tank

\begin{tabular}{ccc}
\hline Parameter & Background & Overset \\
\hline Panjang $(\mathrm{m})$ & 1L dari FP & $0.25 \mathrm{~L}$ dari FP \\
& 2.5L dari AP & $0.25 \mathrm{~L}$ dari AP \\
Tinggi $(\mathrm{m})$ & 1L dari Deck & $0.75 \mathrm{H}$ dari Deck \\
& 2L dari Keel & $0.75 \mathrm{H}$ dari Keel \\
Lebar $(\mathrm{m})$ & 1.5L dari Symmetry & $0.5 \mathrm{~B}$ dari Symmetry \\
\hline
\end{tabular}

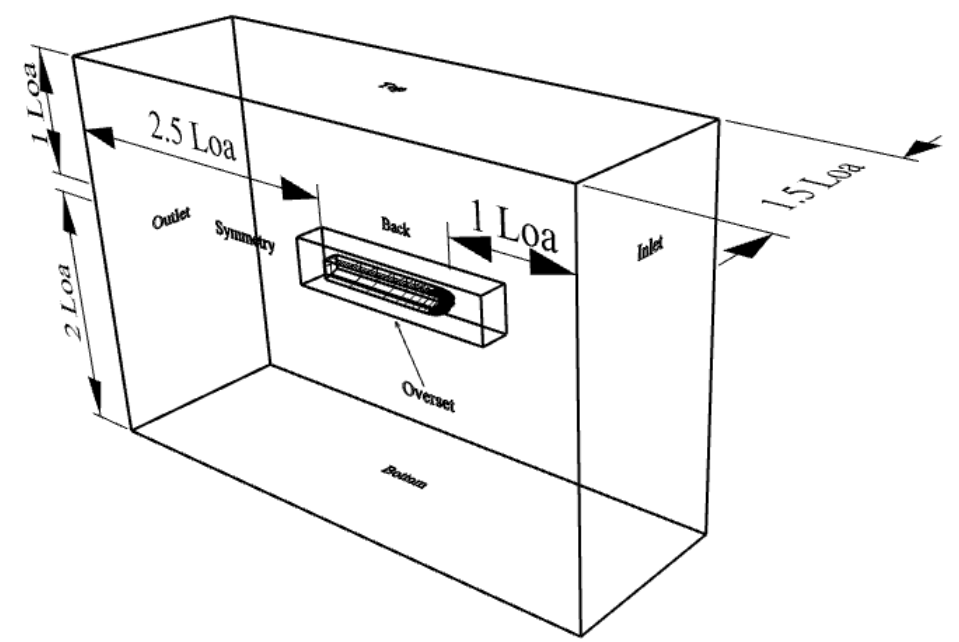

Gambar 4. Ukuran dan surfaces domain

Dengan domain pada geometri ditunjukkan pada Tabel 3.

Tabel 3. Domain pada virtual towing tank

\begin{tabular}{ccc}
\hline Part surfaces & Background & Overset \\
\hline Top & Velocity Inlet & Overset Mesh \\
Bottom & Velocity Inlet & Overset Mesh \\
Inlet & Velocity Inlet & Overset Mesh \\
Outlet & Pressure Outlet & Overset Mesh \\
Back & Velocity Inlet & Overset Mesh \\
Symmetry & Symmetry Plane & Symmetry Plane \\
Half Model & - & No-Slip Wall \\
\hline
\end{tabular}

Kerapatan mesh difokuskan pada objek dan permukaan air agar hasil tetap akurat dalam waktu komputasi yang relatif lebih cepat. Sehingga dibutuhkan beberapa objek sebagai refinement atau merapatkan mesh secara lokal. Dilakukan dengan menggunakan metode anisotropic mesh untuk memfokuskan pada ordinat $\mathrm{x}, \mathrm{y}$, atau z. Perlu diperhatikan bahwa dalam metode overset mesh, kerapatan mesh donor dengan acceptor harus pada dimensi yang sama atau tidak signifkan perbedaannya. Perbedaan yang signifikan dapat mengakibatkan error data transfer, sehingga simulasi tidak dapat dilanjutkan. Pada simulasi ini kerapatan mesh dibagi menjadi beberapa bagian seperti pada Tabel 4 dan Gambar 5. 
Tabel 4. Kerapatan Mesh

\begin{tabular}{cc}
\hline Nama Bagian & Dimensi Mesh \\
\hline Far Field & $0.7874 \mathrm{~L}$ \\
Block 1 & $0.0492 \mathrm{~L}$ \\
Overlap & $0.0246 \mathrm{~L}$ \\
Overset & $0.0246 \mathrm{~L}$ \\
Hull & $0.0062 \mathrm{~L}$ \\
Free Surface & $0.0062 \mathrm{~L}$ \\
\hline
\end{tabular}

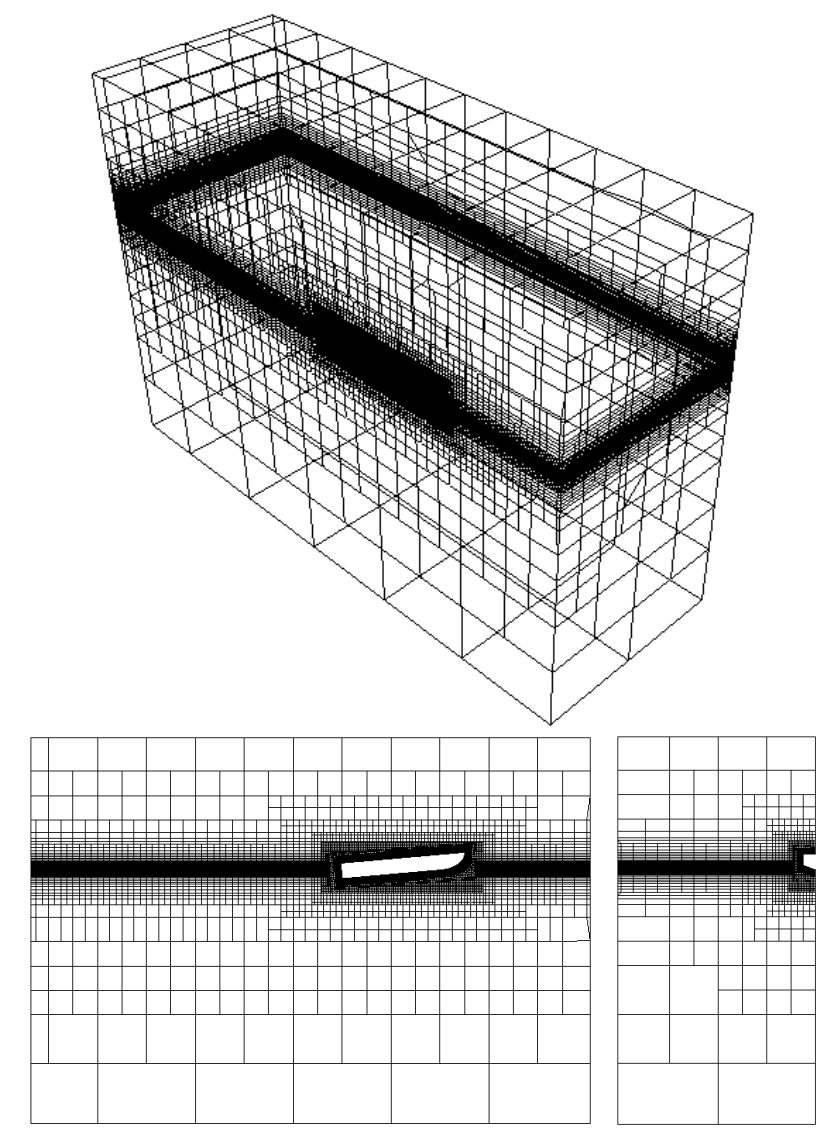

Gambar 5. Ilustrasi kerapatan mesh

Pengaturan meshing dan solver dibedakan berdasarkan kecepatan, wall function $(y+)$, dan $\Delta t$ seperti tertera pada Tabel 5.

Tabel 5. Setup ditiap hullform

\begin{tabular}{ccc}
\hline Parameter & Fridsma F & Fridsma G \\
\hline Number of Prism Layers & 6 & 6 \\
Prism Layer Stretching & 1.2 & 1.2 \\
Prism Layer Thickness $(\mathrm{m})$ & 0.0054 & 0.0038 \\
Current $(\mathrm{m} / \mathrm{s})$ & 3.98 & 5.98 \\
Wind $(\mathrm{m} / \mathrm{s})$ & 3.98 & 5.98 \\
Implicit Unsteady $(\mathrm{s})$ & 0.005 & 0.005 \\
Maximum Inner Iterations & 5 & 5 \\
Maximum Phisical Time $(s)$ & 7 & 7 \\
\hline
\end{tabular}

Rekayasa Hijau - 29 
Pada simulasi CFD gerak kapal dibatasi dengan membebaskan gerak rotasi sumbu $y$ (trim) dan gerak translasi searah sumbu $z$ (heave). Sementara gerakan kapal yang lain tidak digunakan untuk menyesuaikan tujuan penelitian ini.

Metode penyelesaian Numerical Ventilatian Problem (NVP) menurut Ahmet Gultekin terbagi menjadi 2 cara. Pertama, persentase konsentrasi udara yang akan diganti sebesar 15\% (sesuai keadaan volume fraction), sehingga hasil hambatan total dikali 1.15. Cara kedua dengan phase replacement, yaitu mengganti fasa udara menjadi air dengan langkah - langkah sebagai berikut [4] :

1. Sebelum simulasi dimulai, aktifkan terlebih dahulu "Multiphase Interaction" pada menu Physic Model.

2. Stop simulasi setelah konvergen.

3. Visualisasikan "Volume Fraction of Water".

4. Pada menu "Multiphase Interaction", buat baru phase interaction.

5. Pilih "VOF-VOF Phase Interaction Model" dan "VOF Phase Replacement Model".

6. Gunakan "Field Function" pada menu Tools untuk mengganti fasa.

7. Buat rumus "scalar" baru pada menu Field Function dan definisikan sebagai berikut “\$ $\$$ VolumeFractionAir $\}<0.50 "$ " (0.5 yaitu mengganti fase udara sebesar 50\% dari konsentrasi fase udara dan air yang berbaur).

8. Kembali ke menu "Multiphase Interaction", kemudian pilih "Air" untuk "Primary case" dan "Water" untuk "Secondary case". Ini yang dimaksud dengan mengganti fase udara menjadi fase air.

9. Lanjutkan simulasi sebanyak 1x time-step.

10. Visualisasikan kembali "Volume Fraction of Water".

\section{HASIL DAN PEMBAHASAN}

Dalam melakukan simulasi perlu memperhatikan nilai $y+$ (wall function) untuk hasil yang akurat. Nilai $y+$ diusahakan berada di rentang 45-60 dengan cara mengubah tebal prism layer pada setiap kecepatan. Nilai tebal layer pertama dapat dicari dengan Persamaan 2. Kemudian dengan deret matematika didapatkan nilai untuk tebal prism layer yang dapat dilihat pada Tabel 5. Hasil visualisasi nilai $y+$ dapat dilihat pada Gambar 6 .

Time-step merupakan bagian yang perlu diperhatikan nilainya. Berdasarkan rumus ITTC mengenai time-step pada Persamaan 3, diambil nilai 0.005 s untuk mempercepat waktu simulasi. Selain itu, fungsi dari time-step untuk mempercepat konvergen suatu simulasi. Simulasi dapat diakhiri apabila grafik telah konvergen atau memiliki perbedaan nilai yang relatif kecil (stagnan). Dan nilai yang diambil berdasarkan rataan hasil yang telah konvergen.


Gambar 6. Perbandingan nilai $y^{+}$, atas (Fr 1.2), bawah (Fr 1.8) 
Pada planing hull terdapat garis stagnasi (stagnation line) yang berbeda disetiap nilai Froude number (Fr). Garis stagnasi yaitu garis batas hull yang tercelup, sehingga dibelakang garis stagnasi disebut pressure area dan didepan disebut spray area [14]. Garis stagnasi hasil simulasi dapat divisualisasikan melalui nilai tekanan pada Gambar 7, dan nilai tekanan terbesar merupakan posisi garis stagnasi. Sedangkan spray area dapat dilihat pada Gambar 8.

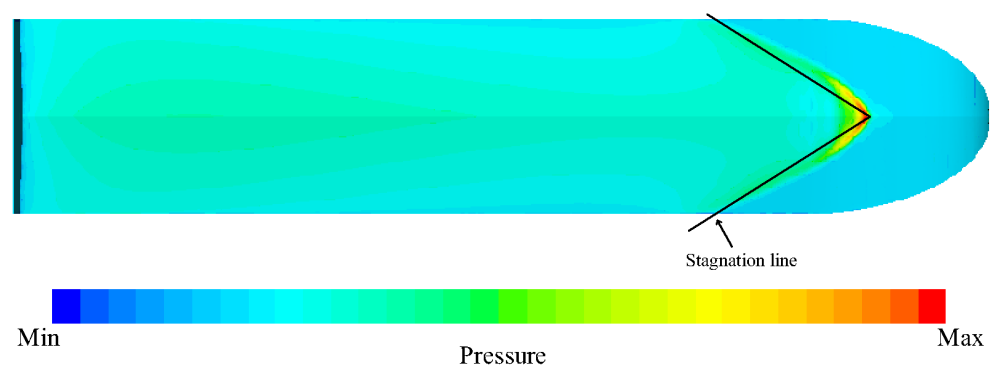

Gambar 7. Visualisasi tekanan pada Fr 1.2



Gambar 8. Visualisasi Wetted Surface Area (WSA)

Karakteristik Fridsma F dan Fridsma G hampir sama, kecuali kecepatanya seperti yang tertera di Tabel 1. Sehingga hanya Froude number yang membedakan. Hal ini memudahkan penyampaian data yaitu sumbu $x$ yang mewakili Fr. Untuk hambatan, sumbu $y$ merupakan non-dimensional unit dari nilai drag per displacement. Untuk nilai trim dalam satuan derajad $\left({ }^{\circ}\right)$. Dan untuk heave, sumbu $y$ merupakan nondimensional unit dari nilai heave (dalam meter) per lebar kapal.

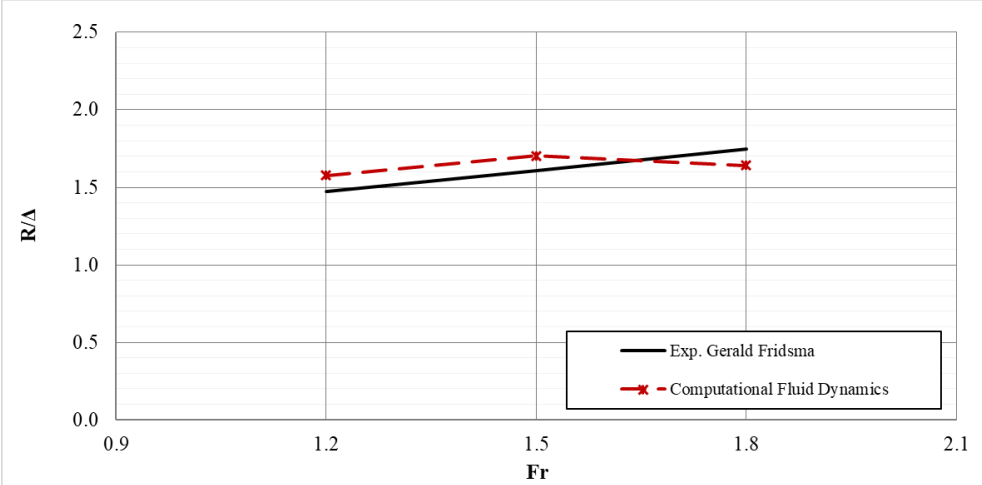

Gambar 9. Perbandingan nilai hambatan CFD dan eksperimen G.Fridsma 




Gambar 10. Perbandingan nilai trim CFD dan eksperimen G.Fridsma

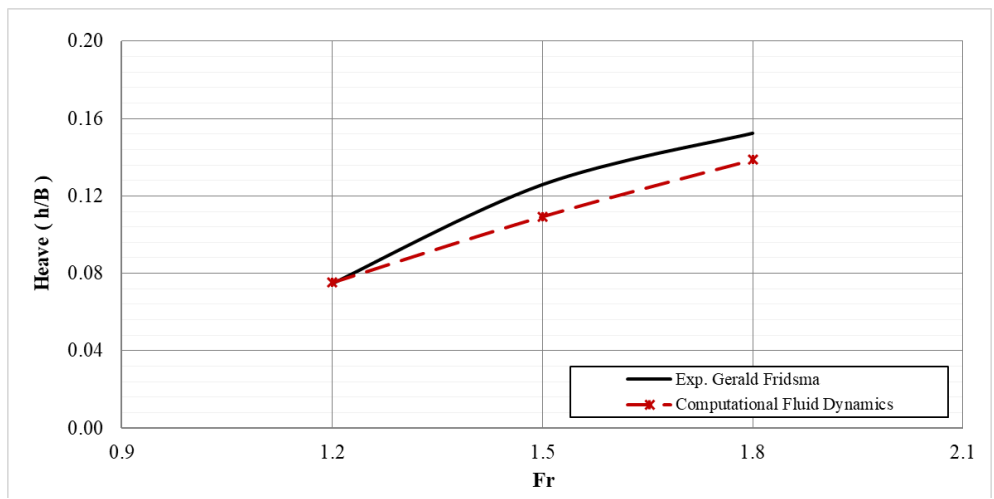

Gambar 11. Perbandingan nilai heave CFD dan eksperimen G.Fridsma

Hasil hambatan menunjukkan terjadinya penurunan tren pada simulasi CFD di Fr 1.8, dapat dilihat pada Gambar 9. Hal tersebut disebabkan karena adanya aliran udara / Numerical Ventilatian Problem (NVP) pada simulasi di Fr 1.8, dapat dilihat pada Gambar 11.

Hasil trim tidak terlalu memiliki tren yang menyimpang seperti pada Gambar 10 dan Gambar 11. Sehingga dapat disimpulkan bahwa hasil simulasi cukup baik dalam memprediksi nilai dari trim. Begitu juga dengan heave yang dibandingkan dengan eksperimen sejenis (tidak terdapat data heave untuk Frisdma $F$ dan $G$ ).
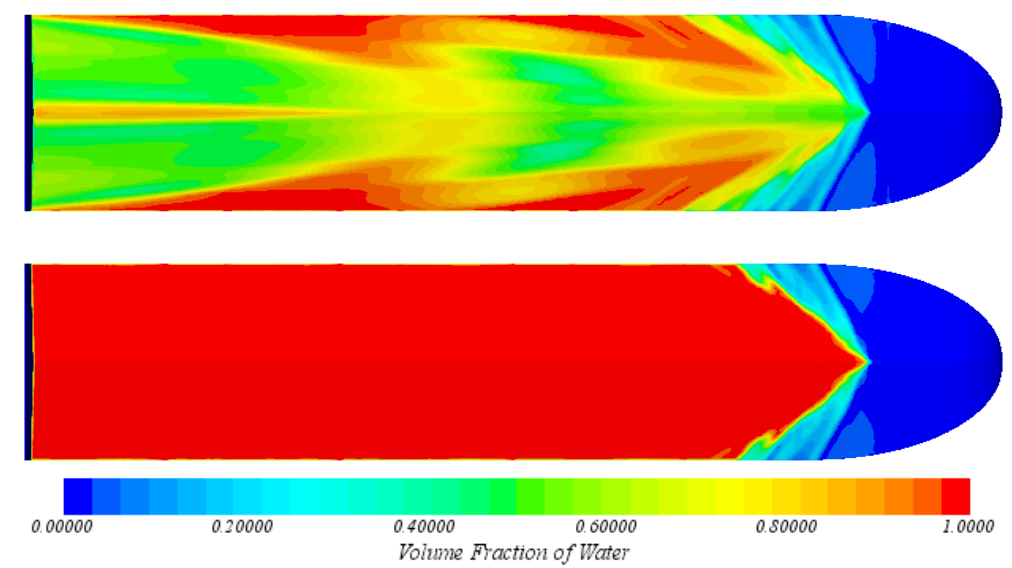

Gambar 12. Visualisasi Wetted Surface Area (WSA), terdapat aliran udara (atas) dan setelah phase replacement (bawah)

Rekayasa Hijau - 32 
Dengan metode phase replacement seperti yang dilakukan oleh Ahmet Gultekin. Didapatkan hasil yang lebih baik dilihat dari tren grafik hambatan yang dapat dilihat pada Gambar 12. Begitu juga dengan visualisasi Wetted Surface Area (WSA) yang tertera pada Gambar 11, menunjukkan kesesuaian dengan keadaan sebenarnya. Namun untuk nilai trim dan heave tidak memiliki perubahan yang berarti, sehingga dapat dikatakan sama dengan keadaan sebelum adanya phase replacement seperti terlihat pada Gambar 9 dan Gambar 10.

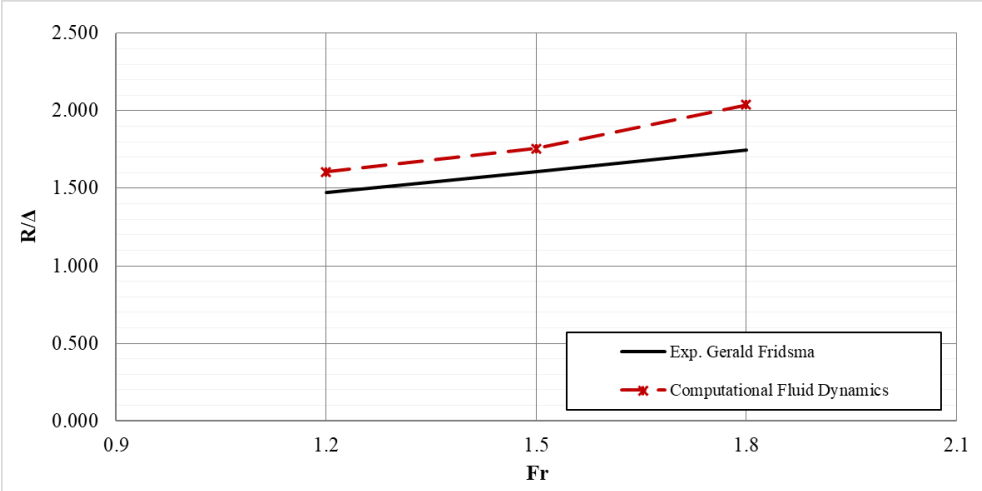

Gambar 13. Perbandingan nilai hambatan CFD dan eksperimen G.Fridsma setelah phase replacement

\section{KESIMPULAN}

Hasil simulasi CFD pada Fr 1.2 hasil cukup baik, namun pada Fr 1.8 terjadi NVP yang mempengaruhi hasil simulasi, sehingga menimbulkan ketidakakuratan terlihat dari trend grafik yang menurun. Setelah dilakukan solusi dengan menggunakan phase replacement, hasil prediksi hambatan menjadi lebih baik. Sementara untuk prediksi trim dan heave, dapat disimulasikan dengan cukup baik. Dapat disimpulkan bahwa metode overset mesh memiliki keakuratan yang baik dalam memprediksi hambatan, trim dan heave kapal bertipe planing.

\section{UCAPAN TERIMA KASIH}

Penulis mengucapan terima kasih kepada Laboraturium Komputer \& Desain Kapal Universitas Diponegoro atas dukungan dalam melakukan penelitian ini.

\section{DAFTAR PUSTAKA}

[1] Fridsma, G. (1969). "A Systematic Study of The Rough-water Performance of Planning Boat," Hoboken, New Jersey,

[2] Iacono, M. (2015). "Hydrodynamics of Planing Hull By CFD," 8, pp. 202.

[3] Faltinsen, O. M. (2005). Hydrodynamics of High-Speed Marine Vehicles, IsBn-13 97. New York: Cambridge University Press.

[4] Avci, A. G. and Barlas, B. (2018). "An experimental and numerical study of a high speed planing craft with full-scale validation," J. Mar. Sci. Technol., 26(5), pp. 617-628.

[5] Nourghasemi, H., Bakhtiari, M. and Ghassemi, H. (2017) "Numerical study of step forward swept angle effects on the hydrodynamic performance of a planing hull," Sci. Journals Marit. Univ. Szczecin, 51(123), pp. 35-42.

[6] Brizzolara, S. and Villa, D. (2010). "CFD Simulation of Planing Hull," in Seventh International Conference On High-Performance Marine Vehicles.

[7] Samuel. (2019). "CFD Analysis on the Interceptor Performance of Planing Boat in Calm Water and Wave," Pukyong National University. 
[8] Samuel, Trimulyono, A. and Santosa, A. W. B. (2019). "Simulasi CFD pada Kapal Planing Hull," KAPAL J. Ilmu Pengetah. \&Teknologi Kelaut., 16(3), pp. 123-128.

[9] Wheeler, M. P., Matveev, K. I. and Xing, T. (2018). "Validation Study of Compact Planing Hulls at Pre-Planing Speeds," in ASME 2018 5th Joint US-European Fluids Engineering Summer Conference FEDSM2018, 2, pp. 1-8.

[10] Sukas, O. F., Cakici, F. and Gokce, M. K. (2014). "Numerical Simulation of Fridsma Hull Using Overset Grid System," in 19th "Numerical Towing Tank Symposium" (Nutts'16).

[11] Launder, B. E. and Spalding, D. B. (1974). "The Numerical Computation of Turbulent Flow Computer Methods," Comput. Methods Appl. Mech. Eng., pp. 269-289.

[12] ITTC. (2011). "Recommended Procedures and Guidelines Practical Guidelines for Ship CFD," (9), pp. 1-18.

[13] Mancini, S. (2015). "The Problem of Verification and Validation Processes of CFD Simulations of Planing Hulls," Università Degli Studi Di Napoli Federico II Dipartimento.

[14] Savitsky, D. (1964). "Hydrodynamic Design of Planing Hulls," Mar. Technol., 1(1), pp. 71-95. 